\title{
Research on Improving Fertility Sandy Soils from Dabuleni Field by Administration of Loess
}

\author{
ANCA LUIZA STANILA ${ }^{2 *}$, CATALIN CRISTIAN SIMOTA ${ }^{1}$, IULIAN RATOI ${ }^{2}$, AURELIA DIACONU2, MIHAIL DUMITRU ${ }^{1}$ \\ ${ }^{1}$ National Research Institute for Soil Science, Agrochemistry and Environment-ICPA, Bucharest, 61 Marasti Blvd., 011464, \\ Bucharest \\ ${ }^{2}$ Research and Development Centre for Plant Growing on Sand Dabuleni, Victoria Str., 207220, Dabuleni, Romania
}

In order to solve and clarifying certain aspects of the clay content (particles $<0.002 \mathrm{~mm}$ ) sands and sandy soils, humus, respectively, the process of bioaccumulation and mineralization the organic matter of the land, in the Research and Development Centre for Plant Growing on Sand Dabuleni, have initiated research aimed at finding methods and means for accumulating and thus the increase in the content of clay in the soil, respectively humus. Therefore, to improve radical of sandy soils, we found it necessary to resort to what is called loess process. It consists in enriching the horizon the surface soil $(20-25 \mathrm{~cm})$ the fraction with 8$10 \%$ clay, to $1.5-5 \%$, as currently it contains. It is primarily intended to influence various amounts loess material on physical, hydro- physical and chemical properties of soils, then the plant response to changes products in the soil, increasing the guaranteed potential fertility of these soils, which will result in production high and constant.Obtaining appropriate agricultural production on sandy soils (eutric psamosol) itis limited not only by the soil, butalso other factors such as relief, drainage and even climate. Because coarse texture, water-holding capacity in the case of sandy soils it is very low in all soils, the clay content below 5\% production capacity of soils it is particularly low in the absence of agropedoameliorative measures and especially irrigation. Wind erosion occurs in all perimeters sandy soils, with higher intensity is observed in Oltenia Plain (Dabuleni Field).

Keywords: sandy soils, fertility, clay, agropedoameliorative measures, alfalfa

This paper develops an idea that has notbeen addressed in the literature global specialty, a priority of Romanian soils research.

Recovery sands and sandy soils is a very topical issue, both nationally and internationally.

The need to increase agricultural production in recent decades has led to the cultivation of agricultural plant surfaces becoming higher these soils.

Sandy soils formed on eolian deposits, although not spread too much, seen as a resource land have a particular importance for the country's agriculture, because it has certain characteristics that make them valuable in relation to plant growth. Among them: warming faster than other soils, thus providing the possibility to obtain early crops; easier work the soil and in a longer time interval, with the energy and lower fuel; greater capacity mineralization of organic matter.
Sandy soils, however, presents a number of shortcomings and limitations of the specific use, but can be relatively easily overcome or offset and other difficult to correct, as is the case granulometry.

The experience increased clay content by loess process on sandy soils (eutric psamosol) under irrigation for culture alfalfa it is stationary and located by the method of the rectangle latin, in randomized blocks in five variants, including the control, with four repetitions, surface experimental plot is $90 \mathrm{~m}^{2}$ ( $12 \mathrm{~m} \times 7.5 \mathrm{~m}$ ) (fig. 1).

The experience carried out in field the culture of alfalfa (Medicago sativa), observations, measurements and laboratory tests included the following:

- setting means, ways and means of increasing clay content of eutric psamosol in the under irrigation;

- speeding up the process of accumulation of humus;

- clarify certain aspects of the mineralization the organic matter of the sandy soils (eutric psamosol);

- administration loess doses;

- use of chemical fertilizers (NPK).

\begin{tabular}{|c|c|c|c|c|c|}
\hline $\begin{array}{c}\text { Variants/ } \\
\text { Repetitions }\end{array}$ & $V_{1}$ & $V_{2}$ & $V_{3}$ & $V_{4}$ & $V_{5}$ \\
\hline $\mathrm{R}_{4}$ & $V_{4} R_{4}$ & $V_{5} R_{4}$ & $V_{1} R_{4}$ & $V_{2} R_{4}$ & $V_{3} R_{4}$ \\
\hline$R_{3}$ & $V_{3} R_{3}$ & $V_{4} R_{3}$ & $V_{3} R_{3}$ & $V_{1} R_{3}$ & $V_{2} R_{3}$ \\
\hline$R_{2}$ & $V_{2} R_{2}$ & $V_{3} R_{2}$ & $V_{4} R_{2}$ & $V_{3} R_{2}$ & $V_{1} R_{2}$ \\
\hline$R_{1}$ & $V_{1} R_{1}$ & $V_{2} R_{1}$ & $V_{3} R_{1}$ & $V_{4} R_{1}$ & $V_{3} R_{1}$ \\
\hline
\end{tabular}

Fig. 1. Main experimental plot is $90 \mathrm{~m}^{2}(12 \mathrm{~m} \times 7.5 \mathrm{~m})$ (fig. 1) 


\section{Experimental part}

Materials and methods

Pedological and agrochemical studies the experimental field within Research and Development Centre for Plant Growing on Sand Dabuleni, been achieved according to the Methodology developed for soil studies, 3 Volumes, ICPA, 1987.

Soil and Agrochemical mapping was performed at 1 : 10.000, using contour maps and soil map, Turnu Magurele sheet, scale 1: 200.000. Soil classification level type, subtype were made in according with Romanian System of Soil Taxonomy (SRTS, 2003, 2012) ICPA, Bucharest.

For field crops located on flat land or sloping average size of the sampling agrochemical is from 2 to $5 \mathrm{ha}$.

The sample average is the agrochemical is a number of partial samples, namely: 25 for uniformly fertilized land.

Partial samples are collected from points arranged in zigzag or parallel directions inside of the harvesting parcel. The depth of the collection is $0-20 \mathrm{~cm}$ arable land. Each sample was partially collected, placed in a box, representing, thus, the average sample agrochemical. Before placing experience in field they were given loess rates and chemical fertilizers - ammonium nitrate (33.5\% $\mathrm{N})$ and complex NPK - 16-16-16 on the surface, namely:

Loess rates:

$\mathrm{V}_{1}$ - no added loess

$\mathrm{V}_{2}^{1}-40$ t/ha

$V^{2}-80$ t/ha

$\mathrm{V}_{4}^{3}-120 \mathrm{t} / \mathrm{ha}$

$\mathrm{V}_{5}^{4}-160$ tha

Complex fertilizer NPK rates of the type: 16-16-16:

$\mathrm{R}_{1}$ - no fertilizer

$\mathrm{R}_{2}^{1}$ - N50 P40 K40

$R_{3}^{2}-N 100$ P80 K 80

$\mathrm{R}_{4}^{3}$ - N150 P $120 \mathrm{~K} 120$

The establishment culture of alfalfa was performed according to the method specified in sandy soils, the ground work is carried out as follows: plowing, discing, rolling before sowing and after sowing, sowing at a depth of $1.5-2 \mathrm{~cm}$ and application of irrigation water to $250 \mathrm{~m}^{3} /$ ha.

The following methods have been used for the physical and hydro-physical features:

Particle size distribution (granulometry):

-pipette method for fractions $<0.002 \mathrm{~mm}$, including;

-wet sieving method for fractions from 0.002 to $0.2 \mathrm{~mm}$ and dried sieving method for fractions $>0.2 \mathrm{~mm}$

For the textural classes and subclasses, we used the Romanian system, according to the Methodology developed for soil studies, ICPA, 1987.

Bulk density (DA) method: metal cylinder of known volume $\left(200 \mathrm{~cm}^{3}\right)$ for the momentary soil moisture.

Total porosity (TP): by computing PT $=(1-A D / D) * 100$

Water permeability $(\mathrm{K})$ : in the laboratory on samples with unchanged alignment taken, the method ICPA

Withering coefficient (CO) was estimated based on the content of clay $(<0.002 \mathrm{~mm})$, using the relationship: CO $(\%)=0.05+0.35 \mathrm{~A}$, where:
$A=$ clay content $<0.002 \mathrm{~mm}$.

Field capacity (CC): bycalculation based on texture and bulk density, $\%$ by weight

Useful water capacity (CU): by calculation from the formula $\mathrm{CU}=\mathrm{CC}-\mathrm{CO}, \%$ by weight

Total water capacity (CT): by calculation from the formula CT=PT/DA, \% by weight

The chemical characteristics were determined using the following methods:

$\mathrm{pH}$ : potentiometrically, with glass and calomel combined electrode, in aqueous suspension, at the ratio of $1 / 2,5$.

Humus: wet oxidation (Walkley-Black method, modified) and results expressed in percentage.

Total nitrogen (Nt): Kjeldahl method, decomposition of $\mathrm{H}_{2} \mathrm{SO}_{4}$ at $350^{\circ} \mathrm{C}$, catalysts: potassium sulphate and copper sullphate.

Available phosphorus (mobile): Egner-Riehm-Domingod method and colorimetric dosed with blue molybdenum, according to Murphy-Riley method (ascorbic acid reduction).

Available potassium (mobile): extraction according to Egner-Riehm- Domingo method and dosing by flame photometry.

Degree of base saturation (V\%): was determined with the following formula $\mathrm{V}=\mathrm{SB} / \mathrm{T}^{*} 100, \%$ by weight

Total cation exchange capacity ( $\mathrm{T}$ me/100 g soil): was determined with the following formula $T$ (me/100 $\mathrm{g}$ soil) $\mathrm{T}=\mathrm{SB}+\mathrm{Ah}$

Hydrolytic acidity (Ah me/100 g soil) was determined by extraction with $1 \mathrm{~N}$ sodium acetate solution buffered to $\mathrm{pH}=8.3$.

Interpretation of the results has been submitted in accordance with Methodology developing soil studies, ICPA Bucharest, 1987, provided for in current legislation on the subject.

\section{Results and discussions}

Experience the culture of alfalfa (Medicago sativa) it was placed on the terrace III of the Danube, on a sand and sandy soils (eutric psamosol) under irrigation and fight against the wind deflation to Research and Development Centre for Plant Growing on Sand Dabuleni, Dolj. The village is located on DN 55, Craiova-Bechet-Corabia, $75 \mathrm{~km}$ south of Craiova and $40 \mathrm{~km}$ west of Corabia.

In terms of taxonomic, soil in the building experience it belongs to the class protisols, namely a eutric psamosol under irrigation conditions.

Eutric psamosoil is characterized by a coarse texture, in which content coarse sand can reach up to $76 \%$, and the clay up to a maximum of $1.1 \%$.

If psamosoils from Oltenia prevails quartz and subordinate orthoclase, microcline, biotite, hornblende, garnet and coil (table 1).

The bulk density varies with the degree of soil formation, the clay content and the humus, it is generally small $\left(D A=1.44 \mathrm{~g} / \mathrm{cm}^{3}\right)$. Shows a very high total porosity $(T P=$

\begin{tabular}{|c|c|c|c|c|c|c|}
\hline \multirow[t]{2}{*}{ Horizon } & \multirow{2}{*}{$\begin{array}{l}\text { Depth } \\
\text { (cm) }\end{array}$} & \multicolumn{2}{|c|}{ Clay } & \multirow{2}{*}{$\begin{array}{c}\text { Silt } \\
0.002-0.02 \mathrm{~mm}\end{array}$} & \multirow{2}{*}{$\begin{array}{c}\text { Fine sand } \\
0.02-0.2 \mathrm{~mm}\end{array}$} & \multirow{2}{*}{$\begin{array}{l}\text { Coarse sand } \\
0.2-2.0 \mathrm{~mm}\end{array}$} \\
\hline & & $<0.002 \mathrm{~mm}$ & $\begin{array}{c}=0.01 \\
\mathrm{~mm}\end{array}$ & & & \\
\hline Aop & $0-20$ & 0.5 & 1.6 & 2.7 & 24.4 & 72.4 \\
\hline Ao & $21-35$ & 0.5 & 1.9 & 2.6 & 24.2 & 72.7 \\
\hline$A C$ & $36-52$ & 0.5 & 1.9 & 2.0 & 21.6 & 75.9 \\
\hline $\mathrm{C}_{1}$ & $53-95$ & 0.7 & 2.2 & 3.0 & 29.3 & 67.0 \\
\hline $\mathrm{C}_{2}$ & $96-132$ & 0.6 & 0.8 & 4.3 & 31.6 & 63.5 \\
\hline $\mathrm{C}_{3}$ & $133-170$ & 1.1 & 3.0 & 4.1 & 33.8 & 61.0 \\
\hline $\mathrm{C}_{4}$ & $171-200$ & 0.9 & 1.2 & 4.1 & 34.0 & 61.0 \\
\hline
\end{tabular}

Table 1

PARTICLE SIZE DISTRIBUTION (GRANULOMETRY) OF EUTRIC PSAMOSOILS 
$49.5 \%)$, making the permeability of these soils, expressed by the hydraulic conductivity to be high $(\mathrm{K}>45 \mathrm{~mm} / \mathrm{h})$. Withering coefficient is very low $(\mathrm{CO}=0.5-1.2 \%)$, but it is an advantage to plants which can realize low moisture water content (table 2).

The chemical reaction of these soils are grouped within the range between 5.65 to 6.45 horizons $A 0$ and $A C$, the weak-moderate acid and at the horizon $\mathrm{C}_{4}$ is neutral $(\mathrm{pH}=$ 7.0) (table 3). In terms of content of humus, eutric psamosoils are generally low in humus, containing from 0.35 to $1.06 \%$. The total cation exchange capacity it is characterized by extremely low values and very small ( $T=4.84-6.33 \mathrm{me} / 100 \mathrm{~g} \mathrm{sol}$ ) and the degree of base saturation is between $68-89 \%$.

Determinations were performed on granulometry and the content of calcium carbonate the loess used in the experimentation before placing experience in the field (table 4, fig. 2).

In the analyzes, coarse sand content ranged between 19.0 and $42.8 \%$, and the fine sand between $64.1 \%$ and $42.8 \%$. Clay contenthave values, and the content of calcium carbonate is medium (5.0 to $9.2 \%$ ).
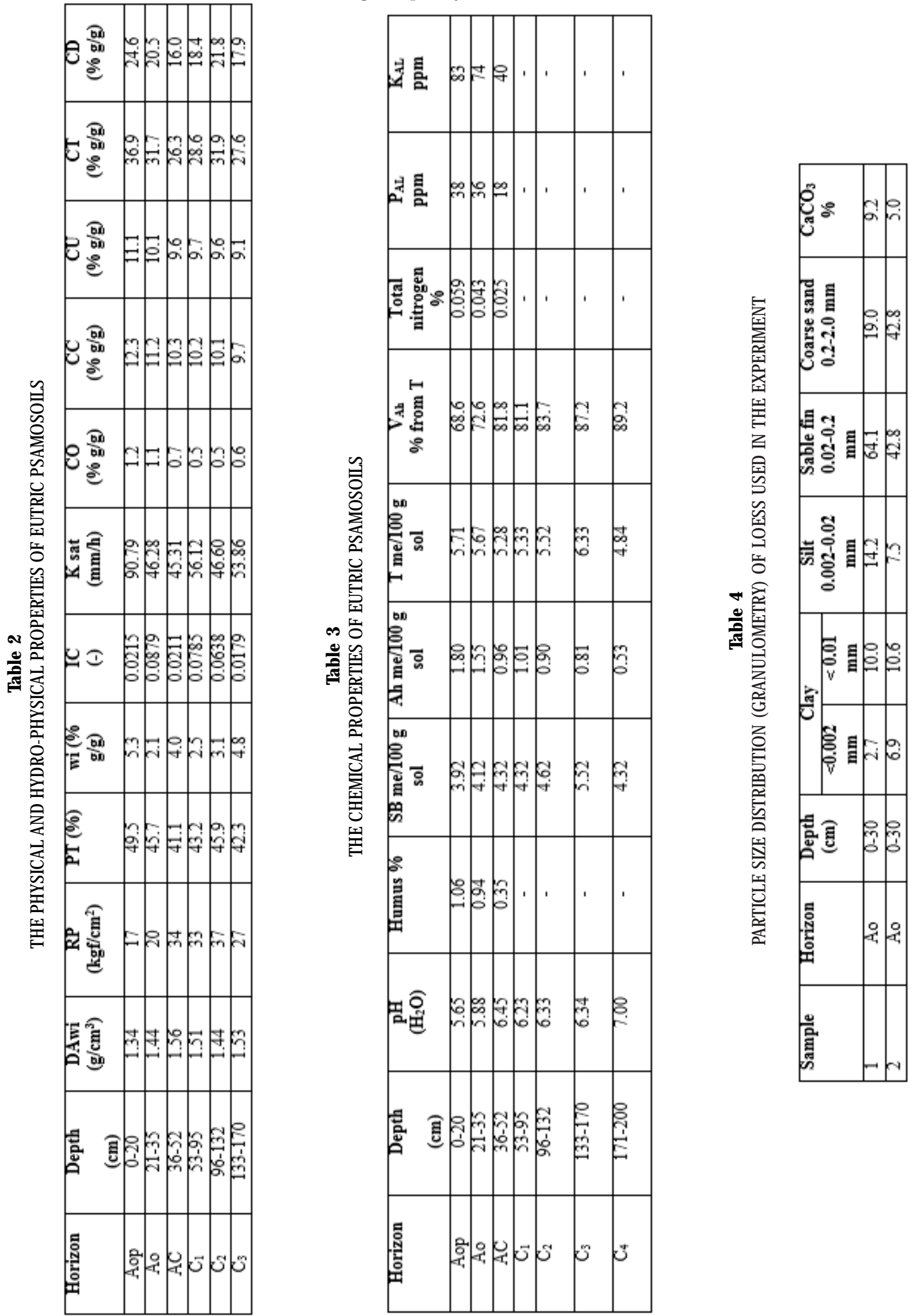


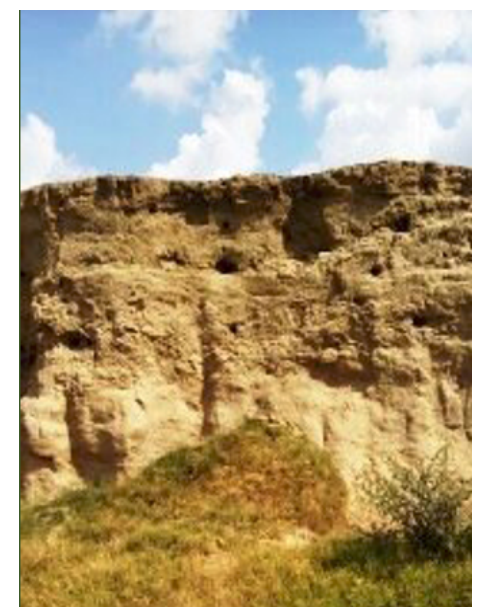

Fig. 2. Source of loess used for experiments on the terrace III Danube the Dabuleni

The materials used as the source of loess they were administered to the soil surface and incorporated by a basic work of the soil (plowing) at a depth of $0-28 \mathrm{~cm}$. Plowing was executed with plow P2V in aggregate with the tractor U650 on 08.30.2017 (fig. 3).

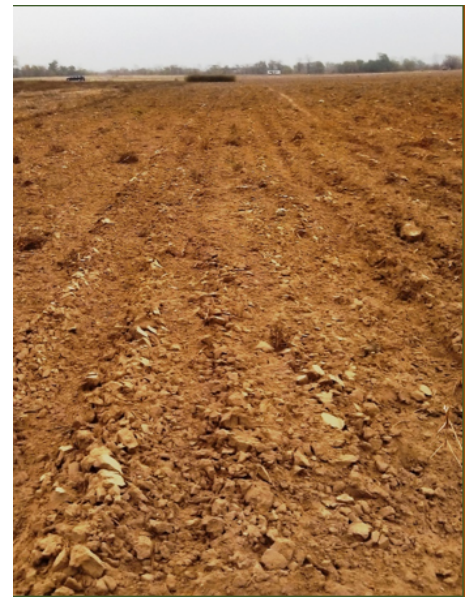

Fig. 3. Plowing executed at $25-28 \mathrm{~cm}$ deep in the experimental field

Semis alfalfa it was done with SUP-21 at a depth of 1.5$2.5 \mathrm{~cm}$ spacing is $12.5 \mathrm{~cm}$, perpendicular to the direction of prevailing winds, on 09.05.2017; ranks were oriented from north to south. Emission seed is $26 \mathrm{~kg} / \mathrm{ha}$ and used alfalfa variety Pomposa.

The rolling after sowing with smooth rolling 3 TN-1,4, on 05/09/2017 and irrigation water $250 \mathrm{~m}^{3} / \mathrm{ha}$, for the seed to find in sandy soils the necessary humidity and placed in contact with the sand for germination. In dry autumns recommended and a second wetting with water 250-300 $\mathrm{m}^{3} /$ ha at an interval of 10-12 days.

Throughout the growing season is recommended that the irrigation to do so to maintain minimum threshold to $50 \%$ of IUA the depth of $80 \mathrm{~cm}$. The necessary water was provided by sprinkler irrigation.

Lack of water from rain and high temperatures high recorded during the vegetation have been necessary to apply irrigation (fig. 4).

Alfalfa (Medicago sativa) has risen on 15.09 .2017 at least $85 \%$, the distance between rows of $12.5 \mathrm{~cm}$ (fig. 5).

Some portions of alfalfa plants have sprung hollow. In phase of 3-5 trifoliate leaves alfalfa plants show different heights from $2 \mathrm{~cm}$ (control variant) to $6 \mathrm{~cm}$ (fertilized variants) on 10/12/2017 (fig. 6, 7).

In the culture of alfalfa stands the presence of dicotyledonous weed, such as: Amaranthus retroflexus, Chenopodium album, Cynodon dactylon, Polygonum aviculare (fig. 8, 9, 10)

On 08/11/2017 alfalfa plants have 7-9 trifoliate leaves and presents different heights at $7 \mathrm{~cm}$ (control variant) up to $13 \mathrm{~cm}$ (fertilized variants).

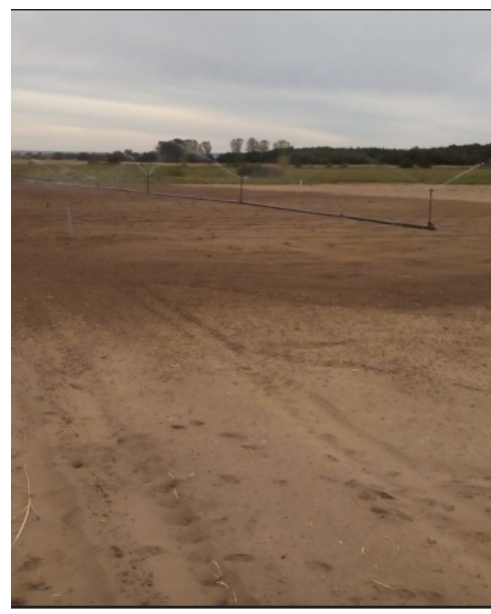

Fig. 4. Sprinkler irrigation system in the experimental field.

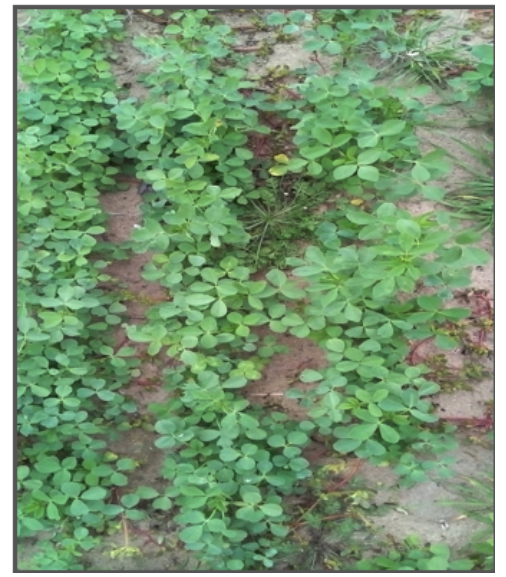

Fig. 5. Culture of alfalfa (Medicago sativa) the distance between rows of $12.5 \mathrm{~cm}$.

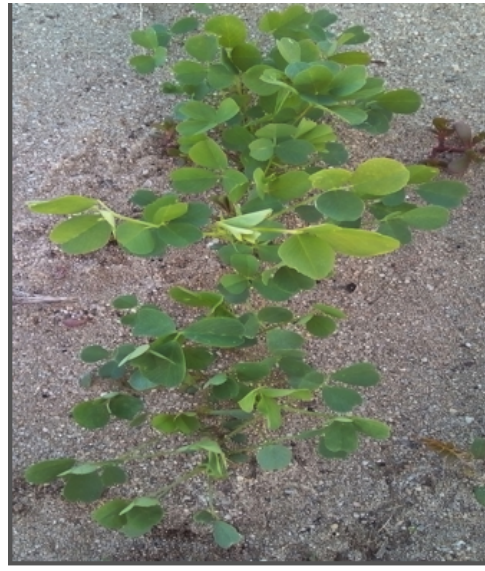

Fig. 6. Alfalfa (Medicago sativa) in phase of 3-5 trifoliate leaves in fertilized variants.

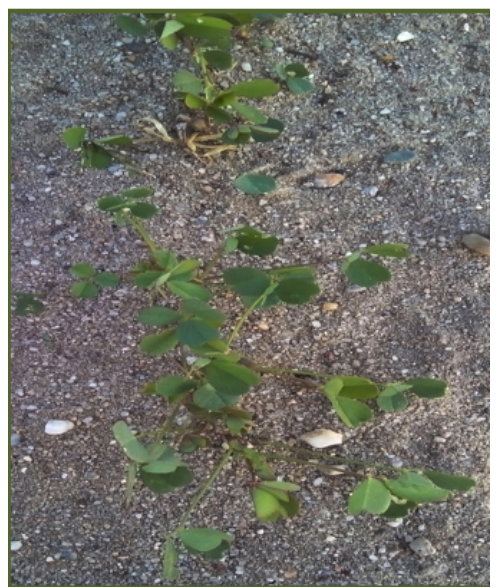

Fig. 7. Alfalfa (Medicago sativa) in phase of 3-5 trifoliate leaves in control variant.

Plant density is $110-120$ plants $/ \mathrm{m}^{2}$ variants fertilized with loess and chemical fertilizer, compared to the control variant where the density is $70-80$ plants $/ \mathrm{m}^{2}$ ( fig. 11- 13). 


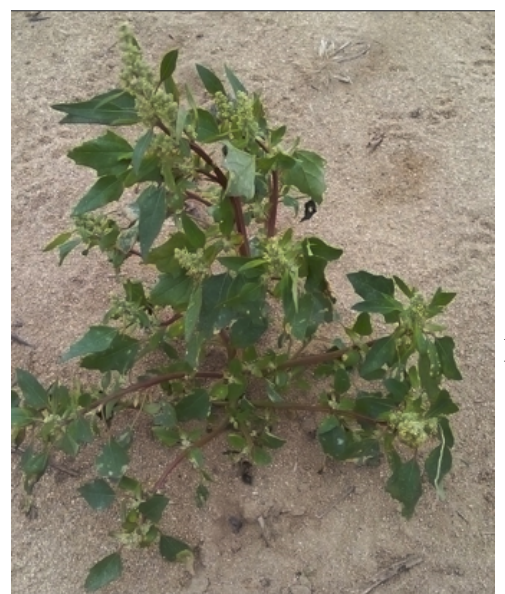

Fig. 8. Amaranthus retroflexus on eutric psamosoils in the Dabuleni Field

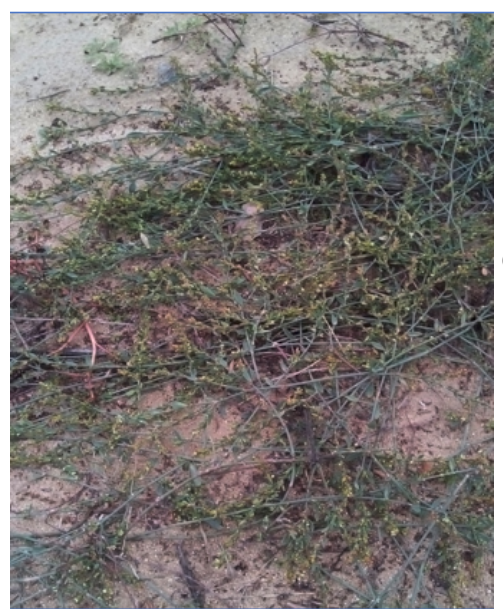

Fig.9. Polygonum aviculare on eutric psamosoils in the Dabuleni Field

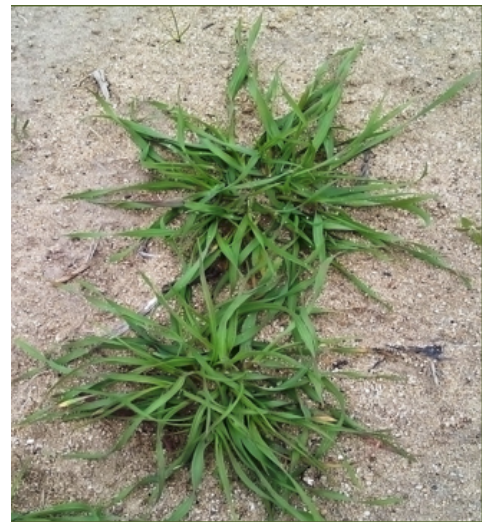

Fig.10. Cynodon dactylon on eutric psmosoils in the Dabuleni Field

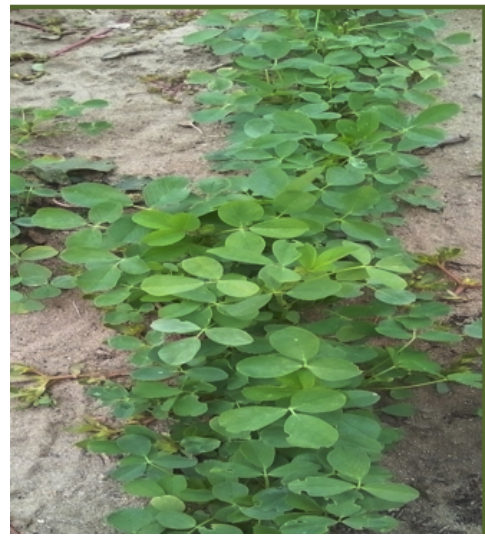

Fig. 11. Alfalfa (Medicago sativa) in phase of 7-9 trifoliate leaves in fertilized variants

\section{Conclusions}

Seeding alfalfa around date 5 September prompted the formation of a strong root system and growth of leaf surface which contributes to achieving high-quality productions. Until the advent of winter frosts, culture of alfalfa (Medicago sativa) $900-1100^{\circ} \mathrm{C}$ has active temperature, which helps

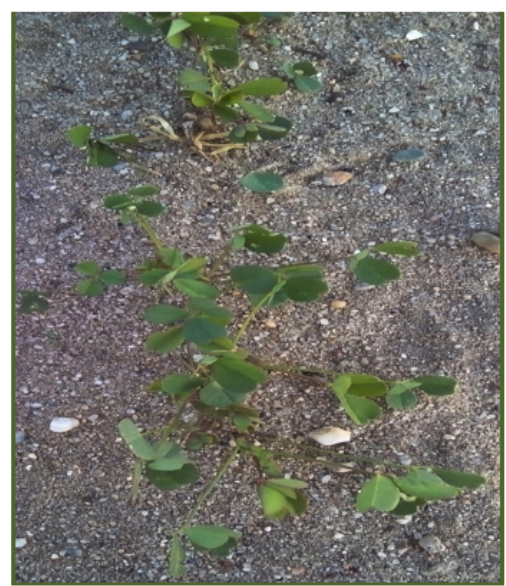

Fig. 12. Alfalfa (Medicago sativa) in phase of 7-9 trifoliate leaves in control variant

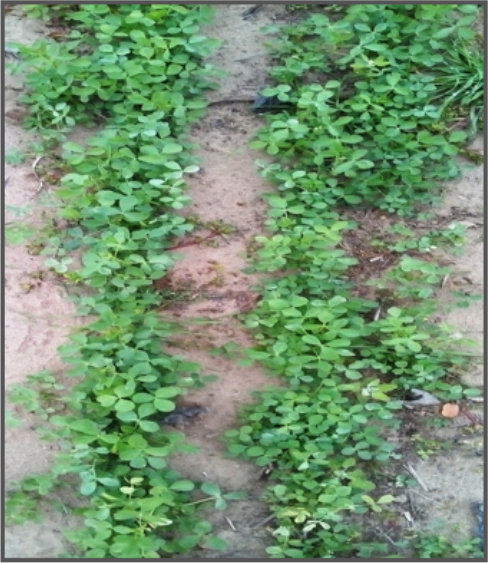

Fig.13. Alfalfa (Medicago sativa) the distance between rows of $12.5 \mathrm{~cm}$ in phase of 7-9 trifoliate leaves

alfalfa plants to take root strong and forming a green carpet, which protects sands against wind deflation.

We will continue phenological observations the culture of alfalfa (Medicago sativa) and also administering chemical fertilizers - ammonium nitrate $(33.5 \% \mathrm{~N})$ and complex NPK -16-16-16 throughout period vegetation.

Acknowledgement: This work was supported by a grant from the Ministry of Research and Innovation, Program Nucleu, contract no. 16N/2016 (Project code PN 16-07 01 09).

\section{References}

1. COTET, P., Romanian Plain. Integrated geomorphology study. Editura Ceres, Bucharest, 1976.

2. FLOREA, N., PARICHI, M., IALBA, MARCELA, RASNOVEANU, I., MUNTEANU, MARIA, Agronomic attributes of sandy soils of R.S. Romania. Ministerul Agriculturii, Bucharest, 1988.

3. FLOREA, N., MUNTEANU, I., RUSU, C., DUMITRU, M., IANOS, GH., RADUCU DANIELA, ROGOBETE GH., TARAU, D., Romanian System of Soil Taxonomy (SRTS). Editura SITECH, Craiova, p. 206.

4. HALALAU, D., PARICHI, M., MACARAU, ST., BANITA, EMILIA, Fodder crops on sands and sandy soils of R.S Romania, Editura Ceres, Bucharest, 1985, p. 167.

5. ISPAS, ST., STANILA, ANCA-LUIZA, Soils Romania, Editura Valahia University Press, Targoviste, 2015, p. 246.

6. OANCEA, C., PARICHI, M., Soils Oltenia Plain of East, Studii tehn. 'i econ., Inst. Geol., Seria C, Bucharest, 1970.

7. OANCEA, C., PARICHI, M., Studies and research on knowledge of soils in Sadova-Corabia irrigation system. Anal. Inst. Cerc. Pedol. of Agr., Vol. XXXIX, p. 527-552, Bucharest, 1972.

8. OPREA, C.V., CRISAN, I., DRAGAN, I., OPRIS, L., POPESCU, G., Contributions to the knowledge and enhancement of the sands in the north-west R.P.Romania. Studii si cerc. Biol., IV/1-2, Timisoara, 1957.

9. PARICHI, M., TRANDAFIRESCU, T., DANILIUC, D., Sandy soils in Romania. Bul. Inf. ASAS, nr. 12, Bucharest, 1978. 
10. PARICHI, M., RASNOVEANU, I., Data on sandy soils of R.S. Romania. Stiinta Solului, nr. 2, p. 24-29, Bucharest, 1983, p. 24-29.

11.PARICHI, M., COZOS, G., Opportunity sandy land leveling in terms of efficient agriculture. Stiinta solului, nr. 1, Bucharest, 1992, p. 12-20. 12.PARICHI, M., STAICU, FILUTA, BANITA, P., Sandy soils of the Romanian Plain. Publicatiile SNRSS, Vol. 29 D, Bucharest, 1997.

13. PARICHI, M., STANILA, ANCA-LUIZA, PLOAE, P., Integrated research on the evolution of territories with landscaped sandy soils. Arhiva ICPA, Bucharest, 1998.

14.PARICHI, M., STANILA, ANCA-LUIZA, The depth of the groundwater in the Romanian Plain between the J iu and Danube. Anal. Univ. Spiru Haret, Seria Geografie, nr. 4, Editura Fundatiei Romania de Maine, Bucharest, 2001, p. 43-47

15. PARICHI, M., STANILA, ANCA-LUIZA, About spatial variability of sandy soils and morphological characteristics, physical and chemical behind the irrigated land planning. Analele Univ. Spiru Haret, Seria Geografie, nr. 5, Editura Fundatiei Romania de Maine, Bucharest, 2002, p.51-59.

16. PARICHI, M., STANILA, ANCA-LUIZA, Soils main relief units in Romania. Editura Fundatiei Romania de Maine, Bucharest, 2006, 179 p.

17. PARICHI, M., STANILA, ANCA-LUIZA, ISPAS, ST., Changes in the pedolandscape of the Romanati Plain (The Field of Dabuleni), Scientific Papers UASVM Bucharest, Series A, Agronomy, Vol. LV, 2012, p. $87-90$.
18. PARICHI, M., STANILA, ANCA-LUIZA, PLOAE, P., Soils wind landscapes of Romania. Editura Fundatiei Romania de Maine, Bucharest, 2013, $146 \mathrm{p}$.

19.RATOI, I., PARICHI, M., STANILA, ANCA-LUIZA, Data pedoagroproductive on sandy soils in southern Oltenia planted with vines. Agricultura Romaniei, nr. 43, Bucharest, 1998.

20. STANILA, ANCA-LUIZA, PARICHI, M., Soil mapping, Editura Fundatiei Romania de Maine, Bucharest, 2001, $160 \mathrm{p}$.

21. STANILA, ANCA-LUIZA, PARICHI, M., Soils Romania, Editura Fundatiei Romania de Maine, Bucharest, 2003, 192 p.

22. STANILA, ANCA-LUIZA, PARICHI, M., Glossary of Soil Science. Editura Fundatiei Romania de Maine, 2005, Bucharest, 108 p.

23. STANILA, ANCA-LUIZA, PARICHI, M., URSARU, P., Pedogeographical observations in the Plain between the Jiu and the Danube. Proceedings, UASVM Bucharest, Series A, Vol. LIII, 2010.

24. STANILA, ANCA-LUIZA, PARICHI, M., What we need to know about soil you work. Editura Fundatiei Romania de Maine, Bucharest, 2012, $72 \mathrm{p}$.

25. STANILA, ANCA-LUIZA, TOTI, M., MUSAT, M., Vulnerability to climatic drought ofthe soils from the Romanian Plain. Soil Forming Factors and Processes from the Temperate Zone, Univ. Al.I.Cuza, Facultatea de Geografie si Geologie, Iasi, p. 83-89.

26.*** Romanian System of Soil Classification. ICPA Bucharest, 1980. 27. *** Methodology development of soil studies (3 Volume), ICPA, Bucharest, 1987.

$\overline{\text { Manuscript received: } 28.03 .2018}$ 